\title{
Evidence for a relation between metabolic derangements and increased levels of inflammatory mediators in a subgroup of patients with chronic obstructive pulmonary disease
}

Annemie M W J Schols, Wim A Buurman, Agnes J Staal-van den Brekel, Mieke A Dentener, Emiel FM Wouters

\begin{abstract}
Background - An increase in resting energy expenditure (REE) commonly occurs in patients with chronic obstructive pulmonary disease (COPD), the cause of which is as yet unknown. The objective of this study was to assess the relationship between REE, acute phase proteins, and inflammatory mediators in patients with COPD.
\end{abstract}

Methods - Thirty patients were studied and 26 healthy age-matched subjects served as controls. REE was measured by indirect calorimetry and adjusted for fat-free mass (FFM) by bioelectrical impedance analysis. Tumour necrosis factor $\alpha$ (TNF- $\alpha$ ), soluble tumour necrosis receptor (sTNF-R) 55 and sTNF-R75, interleukin (IL)-6, IL-8, and lipopolysaccharide binding protein (LBP) were measured by ELISA.

Results - Fourteen patients had a normal REE and in 16 it was raised. The mean body mass index and fat mass were significantly lower in the latter but pulmonary function data were similar in the two groups. In the 30 patients with COPD the mean (SD) sTNF-R75 was 1.7 (1.0) $\mathrm{ng} / \mathrm{ml}$ compared with $1.1(0.4) \mathrm{ng} / \mathrm{ml}$ in the controls; C-reactive protein (CRP) was detectable $(>5 \mu \mathrm{g} / \mathrm{ml})$ in eight patients compared with none of the control subjects, and LBP was $13.2(7.7) \mu \mathrm{g} / \mathrm{ml}$ compared with $8.6(3.1) \mu \mathrm{g} / \mathrm{ml}$ in the controls. The patients with a raised REE had increased mean levels of CRP compared with the patients with a normal REE (median 5.5 $\mu \mathrm{g} / \mathrm{ml}$ (range 5-193) and $<5 \mu \mathrm{g} / \mathrm{ml}$, respectively); the same was true for LBP (median $12.4 \mu \mathrm{g} / \mathrm{ml}$ (range 8.1-39.1) and 9.5 $\mu \mathrm{g} / \mathrm{ml}$ (range 5.0-16.6), respectively), but sTNF-R55 and R75 and IL-8 were similar in the two groups. Of the 16 patients with a raised REE, the CRP level was increased in eight and normal in eight. In those with an increased level of CRP the FFM was decreased and LBP, IL-8, and STNF-R55 and $R 75$ were increased compared with those with normal CRP levels.

Conclusions - A subset of patients with COPD with an increased REE and decreased FFM have increased levels of acute phase reactant proteins and inflammatory cytokines in their serum; these phenomena may be causally related. (Thorax 1996;51:819-824)
Keywords: chronic obstructive pulmonary disease, inflammation, metabolism.

Weight loss and depletion of fat-free mass (FFM) commonly occur in patients with chronic obstructive pulmonary disease (COPD). ${ }^{12}$ That these findings are clinically important is indicated by their adverse relation to physical performance ${ }^{34}$ and survival, ${ }^{4}$ independent of the severity of airflow obstruction. Weight loss in COPD is a result of an imbalance between energy intake and energy expenditure. ${ }^{5}$ Previous studies have shown that resting energy expenditure (REE) is increased in a substantial number of patients with COPD and may be linked to the observed weight loss. ${ }^{6}$

The cause of the increased REE has not yet been elucidated. Several studies have investigated the hypothesis that hypermetabolism in patients with COPD is due to an increased energy consumption of breathing but convincing evidence has not been provided. ${ }^{78}$ Based on experimental animal studies ${ }^{9-11}$ and recent clinical findings, inflammatory mediators such as tumour necrosis factor (TNF)- $\alpha$, interleukin (IL)-1 and IL-6 have been suggested to play a part in the observed metabolic changes associated with chronic wasting diseases such as cancer, cystic fibrosis, and cardiac cachexia. ${ }^{12-14}$ In particular, the presence of inflammation reflected by a hepatic acute phase response $\mathrm{e}^{112^{15}}$ has been suggested to be related to an increase in REE.

In the present study we investigated whether the increased REE seen in some patients with COPD is related to a systemic inflammatory response. The inflammatory mediators TNF- $\alpha$, soluble TNF receptors 55 and 75 (sTNF-R55, sTNF-R75), IL-6 and IL-8 were studied. Furthermore, the acute phase response was monitored by measuring levels of C-reactive protein (CRP) and lipopolysaccharide binding protein (LBP).

\section{Methods}

PATIENTS AND HEALTHY SUBJECTS

Thirty patients of mean (SD) age 61 (6) years with moderate to severe COPD (forced expiratory volume in one second $\left(\mathrm{FEV}_{1}\right)$ of $37(15) \%$ predicted) who met the below mentioned metabolic criteria participated in the study. They were consecutively admitted to an inpatient pulmonary rehabilitation centre in a stable clinical condition. Patients with an increase in $\mathrm{FEV}_{1}$ of more than $10 \%$ of the pre- 
dicted baseline value after administration of a bronchodilator (400 $\mu \mathrm{g}$ salbutamol) or with unstable COPD were excluded from the study. The healthy control group consisted of 26 subjects aged over 50 years with no evidence of COPD, based on questionnaires and lung function testing, who were part of a random population sample of subjects living in the same area as the patients. Their mean age was 59 (5) years and mean $\mathrm{FEV}_{1}$ was $112(16) \%$ predicted. The study was approved by the medical ethical committee of the University Hospital of Maastricht. Written informed consent was obtained from all subjects.

\section{METABOLIC MEASURES}

Body composition was measured by single frequency bioelectrical impedance analysis (RJL Systems, Detroit, USA) in the supine position at the right side. Fat-free mass (FFM) was calculated from height ${ }^{2} /$ resistance and body weight using a group specific regression equation derived from a previous study using deuterium dilution as a reference method. ${ }^{16}$ In order to assess the degree of metabolic tissue depletion, FFM was adjusted for body size by calculating the FFM index (= FFM (kg)/ height $\left.^{2}\left(\mathrm{~m}^{2}\right)\right)$. Fat mass was calculated by subtracting FFM from body weight.

Resting energy expenditure (REE) was measured after an overnight fast under standardised conditions $\mathrm{s}^{17}$ by indirect calorimetry using a ventilated hood (Oxycon Beta, Mijnhardt, Bunnik, The Netherlands) and expressed as a percentage of the Harris-Benedict (HB) prediction equations (REEHB) ${ }^{18}$ and, in addition, adjusted for FFM. ${ }^{19}$ The adjusted REE was calculated as the group mean REE plus measured minus predicted REE, which was the calculated REE obtained by using the individual FFM in the linear regression equation of REE on FFM. Based on the HB prediction equations, patients were prestratified into normometabolic and hypermetabolic groups. Only patients with an REEHB of $<105 \%$ or $>120 \%$ were allowed into the study.

LUNG FUNCTION

Lung function testing included spirometry, transfer factor (KCO), thoracic gas volumes (ITGV, RV, TLC), and airway resistance (Masterlab, Jaeger, Wurzburg, Germany). Values were expressed as a percentage of predicted. ${ }^{20}$

\section{COLLECTION OF PLASMA SAMPLES}

Blood was obtained in the fasting state by venepuncture immediately after measurement of the REE. Blood was collected in evacuated blood collection tubes (Sherwood Medical, St Louis, Missouri, USA) containing 50 units of heparin (Leo Pharmaceutical Products BV, Weesp, The Netherlands). Plasma was separated from blood cells by centrifugation at $1000 \mathrm{~g}$ for five minutes within one hour after collection. Plasma samples were stored at $-20^{\circ} \mathrm{C}$ until analysis.

MEASUREMENT OF INFLAMMATORY MEDIATORS Most inflammatory mediators were measured using a specific sandwich ELISA that has been described elsewhere. ${ }^{21-25}$ In short, for measurement of sTNF-R55 and sTNF-R75, monoclonal antibodies MR1-1 and MR2-2 were used for coating. Specific biotin-labelled polyclonal rabbit anti-human-sTNF-R IgG were used as detector reagents. The standards used were recombinant human sTNF-R55 and sTNF-R75 and the detection limit of both assays was $100 \mathrm{pg} / \mathrm{ml}$. Polyclonal rabbit anti-rh LBP IgG was used as coating for the LBP ELISA and biotin-labelled polyclonal rabbit anti-rh LBP IgG was used for detection of LBP. The standard used was rh LBP. Washing and dilution was performed in buffer containing $40 \mathrm{mM} \mathrm{MgCl}$ to prevent disturbance by lipopolysaccharide of LBP recovery in the ELISA. The detection limit of the assay was $200 \mathrm{pg} / \mathrm{ml}$. IL-6 was coated by monoclonal antibody $5 \mathrm{E} 1$ and detected by polyclonal rabbit anti-human IL- 6 antiserum. IL- 6 could be detected with a lower detection limit of 10 $\mathrm{pg} / \mathrm{ml}$. IL- 8 was coated by the IL- 8 monoclonal antibody HM. 5 and detected by biotinylated polyclonal rabbit anti-human IL-8 IgG. IL-8 could be detected with a lower detection limit of $20 \mathrm{pg} / \mathrm{ml}$. Immunoassay plates (NuncImmuno Plate Maxisorp, Roskilde, Denmark) were used for the ELISA assays. Biotinylated samples were detected with streptavidinperoxidase conjugate (Dako, Glostrup, Denmark) while non-conjugated polyclonal antihuman antiserum was detected by peroxidaseconjugated goat anti-rabbit IgG (Jackson Immunoresearch, West Grove, Pennsylvania, USA) was used in the IL- 6 ELISA. TMB (3,3',5,5'-tetramethylbenzidine, Kirkegaard and Perry Laboratories, Gaithersburg, Maryland, USA) was used as substrate. Photospectrometry $(450 \mathrm{~nm})$ was performed using a micro ELISA autoreader.

CRP was measured by turbidimetric analysis with a detection limit of $3 \mu \mathrm{g} / \mathrm{ml}$. Serum creatinine was used as a relevant renal function parameter and detected by the modified Jassé reaction (Dimension, Dupont, France)..$^{26}$

CONSISTENCY OF STNF-RECEPTOR LEVELS AND LIPOPOLYSACCHARIDE BINDING PROTEIN IN CLINICALLY STABLE PATIENTS WITH COPD

Since to our knowledge no data are available on sTNF receptors and LBP levels in patients with COPD, we determined whether the sTNF receptor levels were consistent over time after 1-8 weeks in 20 clinically stable patients (of whom part were included in this study). The mean difference and agreement limits (mean $-2 \mathrm{SD}$ to mean $+2 \mathrm{SD})$ were $-0.01(-0.33$ to $0.31) \mathrm{ng} / \mathrm{ml}$ for sTNF-R55 and $0.11(-0.53$ to $0.75) \mathrm{ng} / \mathrm{ml}$ for sTNF-R75. The mean difference for LBP was $3.8(-6.2$ to 13.8$) \mu \mathrm{g} / \mathrm{ml}$.

\section{DATA ANALYSIS}

Groups were compared by analysis of variance or by the Mann-Whitney $U$ test where appropriate. The $\chi^{2}$ test was used to compare categorical variables. Results are presented as mean (SD) for normally distributed variables and median (range) otherwise. $p$ values of $<0.05$ were considered statistically significant. The statistical analyses were performed using the SPSS for Windows statistical package. ${ }^{28}$ 
Table 1 Mean (SD) body composition and inflammatory markers in patients with COPD and healthy subjects

\begin{tabular}{|c|c|c|c|}
\hline & $\begin{array}{l}\text { Patients } \\
(n=30)\end{array}$ & $\begin{array}{l}\text { Healthy subjects } \\
(n=26)\end{array}$ & $p$ value \\
\hline$M: F$ & $23: 7$ & $13: 13$ & \\
\hline Body mass index $\left(\mathrm{kg} / \mathrm{m}^{2}\right)$ & $23.5(4.2)$ & $27.0(2.5)$ & $<0.001$ \\
\hline Fat-free mass $(\mathrm{kg})$ & $47.7(2.2)$ & $49.5(7.6)$ & NS \\
\hline Fat mass $(\mathrm{kg})$ & $17.8(7.0)$ & $25.5(5.3)$ & $<0.001$ \\
\hline sTNF-R55 (ng/ml) & $1.4(0.8)$ & $1.0(0.3)$ & NS \\
\hline sTNF-R75 (ng/ml) & $1.7(1.0)$ & $1.1(0.4)$ & $<0.05$ \\
\hline IL-8 ${ }^{1}(\mathrm{pg} / \mathrm{ml})$ & 140 & $<20$ & $<0.001$ \\
\hline $\mathrm{CRP}^{2}(\mu \mathrm{g} / \mathrm{ml})$ & $64.3(79.9)$ & $<5$ & $<0.01$ \\
\hline $\mathrm{LBP}(\mu \mathrm{g} / \mathrm{ml})$ & $13.2(7.7)$ & $8.6(3.1)$ & $<0.001$ \\
\hline
\end{tabular}

sTNF-R55, sTNF-R75 = soluble tumour necrosis receptors; IL-8 = interleukin 8 $\mathrm{CRP}=\mathrm{C}$ reactive protein; $\mathrm{LBP}=$ lipopolysaccharide binding protein.

${ }^{1}$ Mean (SD) of the detectable levels of IL-8 in 17 patients ( $p$ value of $\chi^{2}$ test)

${ }^{2}$ Mean (SD) of the detectable levels of CRP in 8 patients ( $\mathrm{p}$ value of $\chi^{2}$ test)

Table 2 Mean (SD) body composition and lung function in normometabolic and hypermetabolic patients with COPD

\begin{tabular}{lccl}
\hline & $\begin{array}{l}R E E<105 \% \\
(n=14)\end{array}$ & $\begin{array}{l}R E E>120 \% \\
(n=16)\end{array}$ & $p$ value \\
\hline $\mathrm{M}: \mathrm{F}$ & $10: 4$ & $14: 2$ & \\
Body mass index $\left(\mathrm{kg} / \mathrm{m}^{2}\right)$ & $25.2(2.9)$ & $21.8(4.6)$ & $<0.05$ \\
Fat-free mass $(\mathrm{kg})$ & $48.3(8.4)$ & $47.2(6.7)$ & $\mathrm{NS}$ \\
Fat mass $(\mathrm{kg})$ & $20.3(5.3)$ & $15.7(7.7)$ & $<0.05$ \\
Inspiratory vital capacity (\%) & $88.7(19.6)$ & $75.8(19.0)$ & $\mathrm{NS}$ \\
Forced expiratory volume (\%) & $42.3(17.3)$ & $33.9(12.2)$ & $\mathrm{NS}$ \\
Residual volume (\%) & $193.8(59.8)$ & $195.6(64.9)$ & $\mathrm{NS}$ \\
Total lung capacity (\%) & $141.7(41.2)$ & $123.2(36.4)$ & $\mathrm{NS}$ \\
Transfer factor (\%) & $73.1(20.6)$ & $64.2(26.5)$ & $\mathrm{NS}$ \\
\hline
\end{tabular}

REE $=$ resting energy expenditure.

Table 3 Inflammatory markers in normometabolic and hypermetabolic patients with COPD

\begin{tabular}{lccl}
\hline & $\begin{array}{l}R E E<105 \% \\
(n=14)\end{array}$ & $\begin{array}{l}R E E>120 \% \\
(n=16)\end{array}$ & $p$ value \\
\hline sTNF-R55 $(\mathrm{ng} / \mathrm{ml})$ & $0.9(0.7-3.3)$ & $1.1(0.5-3.3)$ & NS \\
sTNF-R75 $(\mathrm{ng} / \mathrm{ml})$ & $1.3(0.8-5.2)$ & $1.4(0.8-3.6)$ & NS \\
IL-6 $(\mathrm{pg} / \mathrm{ml})$ & $10(10-200)$ & $10(10-200)$ & NS \\
IL-8 $(\mathrm{pg} / \mathrm{ml})$ & $30(20-200)$ & $30(20-200)$ & NS \\
CRP $(\mu \mathrm{g} / \mathrm{ml})$ & $<5$ & $5.5(5-193)$ & $<0.005$ \\
LBP $(\mu \mathrm{g} / \mathrm{ml})$ & $9.5(5.1-16.6)$ & $12.4(8.1-39.1)$ & $<0.05$
\end{tabular}

sTNF-R55, sTNF-R75 = soluble tumour necrosis receptors; IL-6, IL-8 = interleukin 6 and 8 $\mathrm{CRP}=\mathrm{C}$-reactive protein; $\mathrm{LBP}=$ lipopolysaccharide binding protein.

Data are expressed as median (range) values; $p$ values from Mann-Whitney $U$ test.

Detection limits: IL-6, 10 pg/ml; IL-8, 20 pg/ml; CRP, $5 \mu \mathrm{g} / \mathrm{ml}$.

\section{Results}

BODY COMPOSITION AND INFLAMMATORY MARKERS IN PATIENTS WITH COPD AND HEALTHY SUBJECTS

Body composition and inflammatory markers were compared between patients and healthy age matched subjects as shown in table 1 . The mean body mass index was significantly higher

Figure 1 Box plot of plasma levels of lipopolysaccharide binding protein (LBP) in hypermetabolic patient with COPD stratified according to the presence of an acute phase response $(C R P>5 \mu \mathrm{g} / \mathrm{ml})$. The dotted line indicates the median value of the healthy subjects; $* p<0.05$

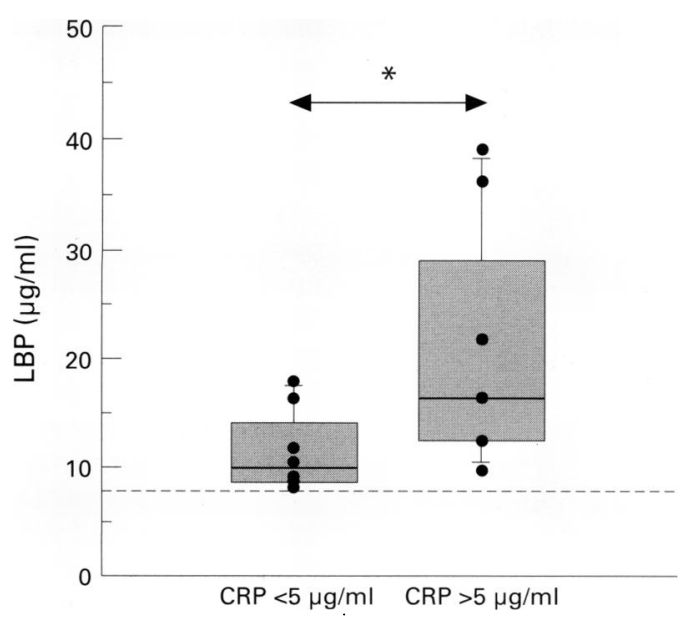

in the healthy subjects due to a larger fat mass. Plasma creatinine levels were within the normal range for all patients and healthy subjects. TNF- $\alpha$ was not detectable with our assay in either the plasma of the healthy individuals or of patients with COPD. No significant difference was seen in sTNF-R55 levels between patients and healthy control subjects but sTNF-R75 was increased in the patients $(p<0.05)$. IL-6 was detectable in three out of 26 healthy subjects compared with 11 of 30 patients with COPD $\left(\chi^{2}=4.7\right.$, $\mathrm{p}<0.05)$. IL-8 was detectable in none of the healthy subjects but in 17 patients $\left(\chi^{2}=21.2\right.$, $\mathrm{p}<0.001)$. Plasma levels of CRP $\left(\chi^{2}=7.5\right.$, $\mathrm{p}<0.01$ ) and LBP (mean difference 4.6 $\mu \mathrm{g} / \mathrm{ml} ; 95 \%$ CI 1.4 to 7.8 ) were significantly increased in the patients.

COMPARISON BETWEEN HYPERMETABOLIC AND NORMOMETABOLIC PATIENTS

In order to discriminate clearly between normometabolic and hypermetabolic patients we prestratified them into two groups to reach a difference in REE expressed as a percentage of the Harris-Benedict (HB) prediction equations of at least $15 \%$ (table 2). In the hypermetabolic group (REE >120\%) a significantly lower body mass index was found, predominantly due to a lower fat mass. Since the HB equations do not take into account possible differences in body composition, and since the FFM is the major determinant of REE, ${ }^{19}$ we investigated whether REE in the hypermetabolic group remained significantly raised when the level was adjusted for the amount of FFM. REE adjusted for FFM was $1661(142.5) \mathrm{kcal} / 24$ hours in the hypermetabolic group and was significantly $(p<0.001)$ higher than the adjusted REE in the normometabolic group (1365 (56.9) kcal/24 hours). Differences in lung function between the two groups were not statistically significant, which may be a consequence of a relatively low power to examine differences between subgroups.

The acute phase proteins were significantly raised in the hypermetabolic patients compared with the normometabolic patients (table 3 ). The patients with detectable levels of IL-6 and IL-8 were equally divided among the hypermetabolic and normometabolic groups and the levels were not significantly different. Furthermore, the sTNF receptor levels were equally enhanced in the hypermetabolic and normometabolic groups.

STRATIFICATION OF HYPERMETABOLIC PATIENTS ON BASIS OF AN ACUTE PHASE RESPONSE We divided the 16 hypermetabolic patients into two groups, eight with normal CRP levels and eight with CRP levels of $>5 \mu \mathrm{g} / \mathrm{ml}$. In the latter group the mean LBP was increased (median difference $6.5 \mu \mathrm{g} / \mathrm{ml}, \mathrm{p}<0.05$; fig 1 ). sTNF-R55 was also increased (median difference $1.1 \mathrm{ng} / \mathrm{ml}, \mathrm{p}<0.05$ ) as was sTNF-R75 (median difference $1.3 \mathrm{ng} / \mathrm{ml}, \mathrm{p}<0.01$ ) (fig 2 ). Detectable levels of IL-6 were 110 (66) pg/ml in four of the eight patients with an acute phase response compared with $50(0) \mathrm{pg} / \mathrm{ml}$ in three of the eight patients without an acute phase 
Figure 2 Box plot of plasma levels of $(A)$ sTNF-R55 and (B) sTNF-R75 in

hypermetabolic patients with COPD stratified according to the presence of an acute phase response $(C R P>5 \mu \mathrm{g} / \mathrm{ml})$. The dotted line indicates the median value of the healthy subjects; $* p<0.05$ $* * p<0.01$.
Figure 3 Box plot of $(A)$ fat-free mass and $(B)$ body mass index in a subset of hypermetabolic patients with COPD stratified according to the presence of an acute phase response (CRP > $5 \mu \mathrm{g} / \mathrm{ml})$. The dotted line indicates the median value of the healthy subjects; $* * * p<0.001$.

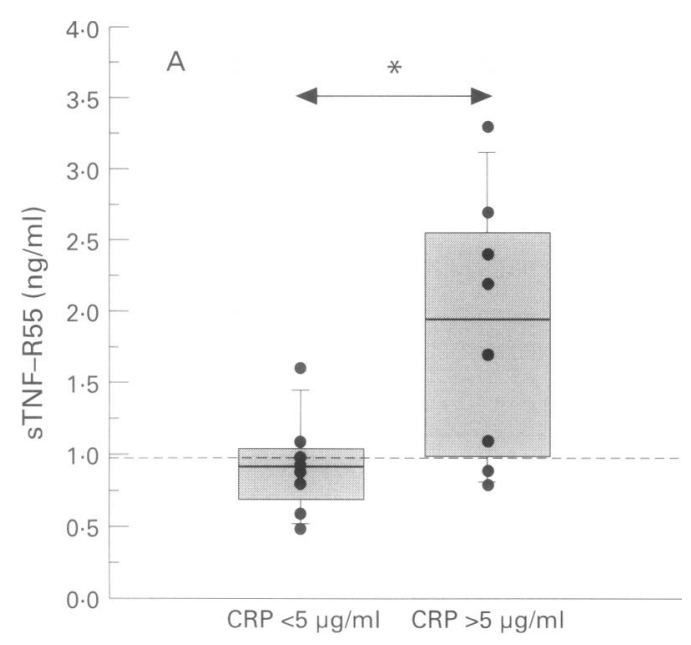

response (NS). Detectable levels of IL-8 were found in six patients in each subgroup, being significantly higher in the group with an acute phase response $(300(140) \mathrm{pg} / \mathrm{ml}$ versus 25 (20) $\mathrm{pg} / \mathrm{ml} ; \mathrm{p}<0.05)$. We also investigated whether the acute phase response was related to body compositional differences between the hypermetabolic patients. A significantly lower FFM index (mean difference $3.0 \mathrm{~kg} / \mathrm{m}^{2}(95 \%$ CI 1.0 to 4.9 ); fig 3) was found in the patients with an acute phase response even after statistical adjustment for the lower body mass index (mean difference $3.1 \mathrm{~kg} / \mathrm{m}^{2}$ (95\% CI -1.5 to 7.9)).

INFLUENCE OF PHARMACOLOGICAL TREATMENT Pharmacological treatment in patients with severe COPD often includes oral corticosteroids and theophyllines which can exert antiinflammatory activities. In our study group maintenance medication consisted of $\beta_{2}$ agonists $(n=25)$, ipratropium bromide $(n=24)$, inhaled corticosteroids $(n=22)$, theophylline $(n=20)$, oral glucocorticosteroids $<15 \mathrm{mg} /$ day $(n=15)$, and diuretics $(n=11)$. Analysis of the relationship between pharmacological treatment and inflammatory mediators only revealed a significant effect for theophylline on both sTNF receptors - that is, significantly lower levels in the subgroup of 20 patients on theophylline treatment compared with the 10 patients not using theophyllines (sTNF-R55 $1.2(0.2)$ versus $1.8(0.3) \mathrm{ng} / \mathrm{ml}, \mathrm{p}<0.05$; sTNF-R75 $1.4(0.2)$ versus $2.2(0.4) \mathrm{ng} / \mathrm{ml}$; $\mathrm{p}<0.05)$.

\section{Discussion}

An increase in REE is a common finding that contributes to tissue wasting in patients with COPD, but the cause of this phenomenon has not yet been elucidated. This study is the first to describe relationships between levels of inflammatory mediators and metabolic derangements in patients with COPD. Significantly increased levels of sTNF-R75, IL-8, and the acute phase proteins CRP and LBP were found in the plasma of a selected group of patients with stable COPD in comparison with healthy age matched individuals. An increased REE was significantly related to raised levels of CRP and LBP. In $50 \%$ of these hypermetabolic patients an acute phase response was defined on the basis of a CRP of $>5 \mu \mathrm{g} / \mathrm{ml}$. This acute phase response was associated, in turn, with increased levels of the inflammatory markers sTNF-R55 and sTNF-R75, IL-8, the acute phase protein LBP, and a selective depletion of FFM.

The high metabolic rate seen in some patients with COPD has been attributed to an increase in respiratory muscle work, since the energy cost of increasing ventilation is higher in patients with advanced disease than in healthy controls of comparable age and sex. ${ }^{7}$ Furthermore, Donahoe et al ${ }^{\beta}$ suggested that the oxygen cost of breathing was significantly higher in patients with COPD who were losing weight due to decreased efficiency of the respiratory muscles. However, we have previously shown that REE does not correlate with individual or 
combinations of detailed lung function tests and blood gas tensions including measurements of volume and transfer factor. ${ }^{5}$ Patients with the poorest lung function - in whom the work of breathing should be the highest - were not necessarily hypermetabolic. Furthermore, a recent study in groups of patients with COPD and chest wall disease revealed no association between oxygen cost of resting augmenting ventilation and REE. ${ }^{7}$ Thus, although an increased work of breathing may contribute to the increased REE, there is no convincing evidence that this is the sole explanation and other factors which could stimulate metabolism have to be considered. The purpose of the present study was to investigate, in clinically stable patients with COPD, the possible relationship between an increased REE and a systemic inflammatory response as reflected by raised levels of cytokines and acute phase proteins.

TNF- $\alpha$ is an important mediator of the host response to infection. ${ }^{29}$ This cytokine modulates the function of lymphocytes and polymorphs at sites of inflammation where its effects are essentially protective to the host. Increased TNF- $\alpha$ production may enhance an injury process locally, and elevated circulating levels may have deleterious systemic effects.

Contradictory results have been reported on the presence of TNF- $\alpha$ in the plasma of patients with COPD. ${ }^{30}{ }^{31}$ Using an immunoradiometric assay Francia et $a l^{30}$ demonstrated increased TNF- $\alpha$ levels in the plasma of patients who were losing weight. Using an ELISA assay which is strongly correlated with the biologically active TNF- $\alpha$, ${ }^{23}$ we were unable to detect TNF- $\alpha$ in our patients. Biologically active TNF- $\alpha$ is difficult to detect because of its short half time and the formation of complexes with the sTNF receptors. Since the presence of TNF- $\alpha$ is reflected by enhanced levels of sTNF receptors, we postulated that measurement of the sTNF receptors could indicate the presence of undetectable levels of TNF- $\alpha$ or, alternatively, merely reflect the enhanced inflammatory status of the patient. The sTNF receptors are considered to be the natural inhibitors of TNF- $\alpha .^{32}{ }^{33}$ Our data show that sTNF-R75, but not sTNF$\mathrm{R} 55$, was significantly increased in the patients when compared with a healthy age-matched control group, possibly related to the different regulatory mechanisms that have been described for both sTNF receptors for the different cell types. ${ }^{34} 35$

In animal models raised levels of TNF- $\alpha$ are associated with anorexia, weight loss, hypertriglyceridaemia, and protein loss. ${ }^{910}$ Acute administration of TNF- $\alpha$ in humans causes an increase in acute phase proteins, provokes an increase of REE, promotes proteolysis and lipolysis, and causes anorexia, ${ }^{36}$ but it is unknown whether these effects are sustained by increased plasma levels of TNF- $\alpha$ in chronic inflammation. In our study sTNF receptor levels were not significantly different between normometabolic and hypermetabolic patients with COPD. However, levels of the acute phase proteins CRP and LBP were significantly increased in the hypermetabolic patients. Further analysis of the acute phase response on the basis of a CRP level of > 5 $\mu \mathrm{g} / \mathrm{ml}$ revealed that an acute phase response was present in none of the normometabolic patients but in $50 \%$ of the hypermetabolic patients. This acute phase response was associated with significantly increased levels of sTNF receptors - both sTNF-R75 and sTNF-R55.

IL-8 has recently been shown to be an important neutrophil chemoattractant in the sputum of patients with cystic fibrosis, bronchiectasis, and in chronic bronchitis. ${ }^{37}$ IL-8 was not detectable in plasma of healthy subjects. To our knowledge no data are available regarding IL-8 levels in the plasma of patients with COPD. In the present study $57 \%$ of the patients had detectable levels which were significantly increased in the group with an acute phase response.

Indirect evidence for our findings is provided by two recent studies which report a relationship between weight loss and TNF- $\alpha$ levels in patients with COPD. Di Francia et $a l^{30}$ described increased serum levels of TNF- $\alpha$ in patients who were losing weight compared with those of a stable weight. Weight loss is difficult to assess accurately and is mostly based on retrospective subjective information. In relation to inflammation it may be important to know the pattern and duration of weight loss. We recognise that in our study there was a very wide range of patterns of relationship between inflammation, hypermetabolism, and depletion of FFM ranging from none to apparent linkage which could be biased by the influence of recent weight loss. Our data do not establish a cause/effect relationship. Hypermetabolism in combination with an acute phase response could also be a response to a negative energy balance. However, the patients were weight stable at the time of measurement (data not shown). Clearly, future longitudinal studies are needed to investigate whether the relationship between metabolic derangements and inflammation involves a sustained systemic effect of acute inflammatory exacerbations or indicates a chronic inflammatory state.

The finding of normal levels of inflammatory mediators in some hypermetabolic patients with COPD suggests that the increase in REE must be multifactorially determined and that, in a cross sectional analysis such as this, it may be difficult to identify all the factors contributing to an increased REE in these patients. An interesting example is the potential influence of pharmacological treatment. A recent study in healthy volunteers reported an increase in REE of about $10 \%$ after theophylline treatment. ${ }^{38}$ In the present study in patients with severe COPD we showed no effect of theophylline treatment at therapeutic plasma concentrations on REE. However, significantly lower levels of both sTNF receptors were observed in patients who were receiving theophylline treatment. These preliminary data support experimental animal and in vitro data which show that, in addition to its activity as a bronchodilator, theophylline has several anti-inflammatory activities such as the inhibi- 
tion of synthesis and release of cytokines including TNF- $\alpha$, the inhibition of inflammatory cell activation and microvascular leakage, and the prevention of hyperresponsiveness induced by airway inflammation. ${ }^{39}$

We have previously reported that depletion of FFM commonly occurs in patients with severe COPD - not only in relation to weight loss but also in those of stable weight. ${ }^{1}$ In this study all the hypermetabolic patients tended to weigh less than the normometabolic group, the difference merely reflecting loss of fat mass which could be attributed to a negative energy balance. A selective depletion of FFM, however, was found in those hypermetabolic patients who exhibited an acute phase response. This finding suggests that a catabolic response may be present in this subgroup and is consistent with the hypothesis that, during an acute phase response, cytokines redirect host protein metabolism away from peripheral tissues such as muscle and towards the liver. ${ }^{12}$ Our data contradict those of Goldstein et $a l^{40}$ who suggested that hypermetabolism in patients with COPD is not associated with hypercatabolism. Other evidence for the presence of a catabolic response in some (hypermetabolic) patients is provided by the disappointing results of nutritional support studies on body weight and FFM. In this respect, inflammatory mediators could be useful markers to include in the selection and follow up of interventions aimed at reversal of tissue depletion in patients with COPD.

This study was supported by a research grant from Glaxo BV. The authors acknowledge the technical assistance of $M$ Akkermans and thank Dr M Robinson of Celltech, Slough, UK for providing the NSO-10 and NSO-23 cells producing, respectively, sTNF-R55 and sTNF-R75 consisting of the extracellular tively, s TNF-R5 and STNF-R75 consisting of the extracellula parts of both TNF-R55 and TNF-R75. Human recombinan Palo Alto, California, USA, human recombinant IL-6 by W Palo Alto, California, USA, human recombinant IL-6 by W Sebald, Physiologisch-Chemisches Institut der Universität, Wurzburg, Germany, and human recombinant IL-8
Lindley, Sandoz Forschungsinstitute Vienna, Austria.

1 Schols AMWJ, Soeters PB, Dingemans AMC, Mostert R, Frantzen PJ, Wouters EFM. Prevalence and characteristic of nutritional depletion in patients with stable COPD eligible for pulmonary rehabilitation. Am Rev Respir Dis 1993;147:1151-6.

2 Engelen MPKJ, Schols AMWJ, Baken WC, Wesseling GJ, Wouters EFM. Nutritional depletion in relation to respiratory and peripheral skeletal muscle function in an out-patient population with chronic obstructive pulmoout-patient population with chronic ob

3 Schols AMWJ, Mostert R, Soeters PB, Wouters EFM. Body composition and exercise performance in chronic obstructive pulmonary disease. Thorax 1991;46:695-9.

4 Wilson DO, Rogers RM, Wright E, Anthonisen NR. Body weight in chronic obstructive pulmonary disease. $\mathrm{Am} \mathrm{Re}$ Respir Dis 1989;139:1435-8.

5 Schols AMWJ, Soeters PB, Saris WHM, Wouters EFM Energy balance in patients with chronic pulmonary disease. Am Rev Respir Dis 1991;143:1248-52.

6 Schols AMWJ, Fredrix EWHM, Soeters PB, Westerterp $\mathrm{KP}$, Wouters EFM. Resting energy expenditure in patients with chronic obstructive pulmonary disease $\mathrm{Am} \mathcal{F} \mathrm{Clin}$ Nutr 1991;54:983-7.

7 Sridhar MK, Carter R, Lean MEJ, Banham SW. Resting energy expenditure and nutritional state of patients with increased oxygen cost of breathing due to emphysema, increased oxygen cost of breathing due to emphyse

8 Donahoe M, Rogers RM, Wilson DO, Pennock BE. Oxygen Donahoe $M$, Rogers RM, Wilson DO, Pennock BE. Oxygen
consumption of the respiratory muscles in normal and consumption of the respiratory muscles in normal and malnourished patients with chronic obstructive

9 Tracey KJ, Wei H, Manogue KR, Fong Y, Hesse DG, Nguyen HT, et al. Cachectin/tumor necrosis factor induces cachexia, anemia and inflammation. $\mathcal{F}$ Exp Med 1988 167:1211-27.

10 Fong Y, Moldawer, Marano M, Wei H, Barber A, Manogue $\mathrm{K}$, et al. Cachectin/TNF or IL- $1 \alpha$ induces cachexia with redistribution of body proteins. Am $\mathcal{F}$ Physiol 1989; 25:R659-65.
11 Strassman G, Fong M, Kenney JS, Jacob CO. Evidence for the involvement of interleukin 6 in experimental cancer cachexia. $\mathcal{F}$ Clin Invest 1992;89:1681-4.

12 Falconer SJ, Fearon KCH, Plester CE, Ross JA, Carter DC. Cytokines, the acute phase response and resting energy expenditure in cachectic patients with pancreatic cancer. Ann Surg 1994;219:325-51.

13 Levine B, Kalman J, Mayer L, Fillit HM, Packer M. Elevated circulating levels of tumor necrosis factor in severe chronic heart failure. N Engl F Med 1990;323:23641.

14 Brown M, Morgan WJ, Finley PR, Scuderi P. Circulating levels of TNF- $\alpha$ and IL- 1 in cystic fibrosis. Pediatr Pulmonol 1991;10:86-91.

15 Staal-van den Brekel A, Schols AMWJ, ten Velde GPM, Buurman WA, Wouters EFM. Analysis of the energy balance in lung cancer patients. Cancer Res 1994;54:6430-3.

16 Schols AMWJ, Wouters EFM, Soeters PB, Westerterp KR. Body composition by bioelectrical impedance analysis compared to deuterium dilution and skinfold anthropometry in patients with chronic obstructive pulmonary disease. Am $\mathcal{F}$ Clin Nutr 1991;52:421-4.

17 Schols AMWJ, Schoffelen P, Ceulemans H, Wouters EFM, Saris WH. Measurement of resting energy expenditure in

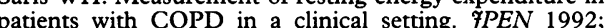
16:364-8.

18 Harris JA, Benedict FG. A biometric study of basal metabolism in man. Washington DC: Carnegie Institute of Washington; 1919, Publication 279.

19 Ravussin E, Bogardus C. Relationship of genetics, age and physical fitness to daily energy expenditure and fuel utilization. Am $\mathcal{F}$ Clin Nutr 1989;49:968-75.

20 Quanjer PH, ed. Standardized lung function testing. Bull Eur Physiopathol Respir 1983;19:7-44.

21 Leeuwenberg JFM, Jeunhomme GMMA, Buurman WA. Slow release of soluble TNF-receptors by monocytes in vitro. F Immunol 1994;152:4036-43.

22 Froon AHM, Dentener MA, Greve JWM, Ramsay G, Buurman WA. LPS toxicity regulating proteins in bacteremia. $f$ Infect Dis 1995;171;1250-7.

23 Engelberts I, Moller A, Schoen GJM, van der Linden CJ, Buurman WA. Evaluation of measurement of human TNF by ELISA. Lymphokine Cytokine Res 1991;10:69-76.

24 Dentener MA, Bazil V, Von Asmuth EJU, et al. Involvement of CD14 in lipopolysaccharide-induced tumor necrosis factor- $\alpha$, interleukin- 6 and interleukin- 8 release by human factor- $\alpha$, interleukin- 6 and interleukin-8 release by human 150:2885-91.

25 Bouma MG, Stad RK, Van den Wildenberg J, Buurman WA. Differential regulatory effects of adenosine on cytokine release by activated human monocytes. F Immunol 1994;153:4159.

26 Larsen K. Creatinine assay by a reaction-kinetic approach. Clin Chim Acta 1972;41:209-17.

27 Froon AHM, Bemelmans MHA, Greve JW, van der Linden $\mathrm{CJ}$, Buurman WA. Increased plasma concentrations of soluble tumor necrosis factor receptors in sepsis syndrome: correlation with plasma creatinine values. Crit Care Med 1994;22:803-9.

28 SPSS for Windows, release 6.0. New York: MJ Norusis/ SPSS Inc, 1993.

29 Tracey KJ, Vlassara H, Cerami A. Cachectin/tumour necrosis factor. Lancet 1989;ii:1123-5.

30 Di Francia M, Barbier D, Mege JL, Orehek J. Tumor necrosis factor alpha levels and weight loss in chronic obstructive pulmonary disease. Am 7 Respir Crit Care Med 1994;150:1453-5.

31 de Godoy I, Calhoun WJ, Donahoe M, Mancino J, Rogers RM. Cytokine production by peripheral blood monocytes of COPD patients. Am $f$ Respir Crit Care Med 1994; 149:A1013.

32 Seckinger P, Isaaz S, Dayer JM. Purification and biologic characterization of a specific tumour necrosis factor $\alpha$ inhibitor. $\mathcal{F}$ Biol Chem 1989;264:1 1966-73.

33 Engelmann H, Aderka D, Rubinstein M, Rotman D, Wallach D. A tumour necrosis factor-binding protein purified to homogeneity from human urine protects cells from tumour necrosis factor toxicity. F Biol Chem 1989; 264:11974-80.

34 Leeuwenberg JFM, Dentener MA, Buurman WA. Lipopolysaccharide LPS-mediated soluble TNF receptor release saccharide LPS-mediated soluble TNF receptor release and TNF recepto

35 Porteu F, Hieblot C. Tumour necrosis factor induces a selective shedding of its p75 receptor from human neutrophils. $\mathcal{F}$ Biol Chem 1994;269:2834-40.

36 Van der Poll T, Sauerwein HP. Tumour necrosis factor- $\alpha$ its role in the metabolic response to sepsis. Clin $\mathrm{Sci}$ 1993;84:247-56.

37 Richman-Eisenstat JBY, Jorens PhG, Hebert CA, Ueki I, Nadel JA. Interleukin-8: an important chemoattractant in sputum of patients with chronic inflammatory airway dissputum of patients with chronic inflamm Cell Mol Physiol 8):L413-8.

38 Dash A, Agrawal A, Venkat N, Moxham J, Ponte J. Effect of oral theophylline on resting energy expenditure in normal oral theophylline on resting energy exp

39 Barnes PJ, Pauwels RA. Theophylline in the management of asthma: time for reappraisal? Eur Respir F 1994;7:579-91.

40 Goldstein SA, Thomashow BM, Kvetan V, Askanazi J, Kinney JM, Elwyn DH. Nitrogen and energy relationships in malnourished patients with emphysema. Am Rev Respir Dis 1988;138:636-44. 